Bernard Łukańko*

b.lukanko@inp.pan.pl

Institute of Law Studies of the Polish Academy of Sciences

72 Nowy Świat, 00-330 Warszawa, Poland

\title{
The Implementation Process of Directive 2014/60/EU of the European Parliament and of the Council in Austrian Legislation
}

\begin{abstract}
This article presents the process of implementing Directive 2014/60/EU of the European Parliament and of the Council in Austrian law, focusing on a presentation of the solutions set out in the draft act as well as of amendments made in the course of parliamentary proceedings. In particular, the analysis includes: the work record, aims and objective scope of the act, the notion of "unlawful removal of a cultural object", the ban on imports, legal definitions, the obligations of care and attention, pursuing claims, court jurisdiction, compensation and other claims, and Austria's claim to return a cultural object. The article concludes that Austria's interest in combating illegal imports of cultural objects has grown considerably. It seems that the Act as adopted can significantly reduce the illicit trafficking of cultural objects from other states to the territory of Austria. The new solutions, including longer periods for pursuing claims, will allow authorised persons to recover lost cultural objects in more cases.
\end{abstract}

Keywords: Cultural property, Austria, EU legislation, cultural significance, criminal liability

\footnotetext{
* Bernard Łukańko holds a LL.M. degree in Legal Studies from the European University Viadrina in Frankfurt/Oder (Germany) and he was a doctoral researcher at the Humboldt University in Berlin where he obtained his PhD in European Private Law. Currently, he works at the Department of International Public Law at the Institute of Law Studies of the Polish Academy of Sciences in Warsaw (Poland).
} 


\section{Introduction}

Pursuant to Article 19(1) of Directive 2014/60/EU of the European Parliament and of the Council of 15 May 2014 on the return of cultural objects unlawfully removed from the territory of a Member State and amending Regulation (EC) No. $1024 / 2012,{ }^{1}$ its implementation in national legislations was to be carried out by 18 December 2015 (hereinafter: Directive2014/60/EU). ${ }^{2}$ Not all national legislators fulfilled the obligation imposed on them in a timely fashion. ${ }^{3}$ The implementation was also delayed in Austria, where the act implementing directive 2014/60/EC - the Federal Act on the return of unlawfully removed cultural objects (Bundesgesetz über die Rückgabe unrechtmäßig verbrachter Kulturgüter [Kulturgüterrückgabegesetz - KGRG]) (hereinafter: the Act), was published on 13 April 2016, ${ }^{4}$ and in accordance with para. 26 sentence 1 of the Act, entered into force on 14 April 2016. This article - as has been indicated in the title - presents the process of implementing the Directive in the Austrian law, including a presentation of solutions set out in the draft act as well as amendments made in the course of parliamentary proceedings. ${ }^{5}$

\section{Current legislation in force}

The Austrian Act of 5 December 1918 on the protection of cultural objects and the ban on exports of cultural objects was, ${ }^{6}$ viewed from today's perspective, a historical precedent in Austrian law that had a major impact on the scope of protection

1 OJ L 159, 28.05.2014, p. 1.

2 Issues relating to the historical preparation of Directive 2014/60/EU are discussed in the article by M. Górka, which is incorporated in this volume.

3 For instance, see the Polish Draft Act on National Cultural Objects [ustawa o narodowych dobrach kultury - projekt], the enactment of which is scheduled by the parliament for the $4^{\text {th }}$ quarter of 2016: http://bip.kprm.gov.pl/kpr/form/r2047,Projekt-ustawy-o-narodowych-dobrach-kultury.html [accessed: 29.12.2016].

4 Bundesgesetzblatt für die Republik Österreich, 2016, T. I, Pos. 19.

5 Issues relating to the UNESCO Convention on the Means of Prohibiting and Preventing the Illicit Import, Export and Transfer of Ownership of Cultural Property (14 November 1970, 823 UNTS 231) (hereinafter: 1970 UNESCO Convention) have been presented only as a side note and included exclusively in order to provide a fuller picture of the Austrian Act implementing the Directive. At the same time, it should be borne in mind that the obligation to implement an EU Directive in national legislation (by a specified date), and the obligation to implement the solutions of an international convention in national legislation, are based on entirely different grounds. In this case - due to the partially-shared scope of their regulation - both of these acts were implemented by way of a single national act of law - the Act.

6 Ausfuhrverbotsgesetz für Kulturgut (AusfVKG) [Austrian Act of 5 December 1918 on the protection of cultural objects and the ban on exports of cultural objects], StGBI. No. 90/1918, as amended. The enactment of the Act was prompted by the predatory removal of cultural objects from Austria towards the end of the First World War. See E. Frodl-Kraft, Gefährdetes Erbe: Österreichs Denkmalschutz und Denkmalpflege 1918-1945 im Prisma der Zeitgeschichte, Böhlau Verlag, Wien 1997, p. 6. 
of cultural objects from unlawful exports. Section para. 1(1) of the Act ${ }^{7}$ laid down a ban on exports of any cultural objects of public interest from Austria without first obtaining a relevant license. ${ }^{8}$ This covered temporary removal as well. Under the Act, and in accordance with the legal definition contained therein, cultural objects included objects of historical significance, art objects, and objects of other cultural importance. Pursuant to para. 1(3) of the Act, the public interest was implied. ${ }^{9}$ Para. 2(2) of the Act set out powers for issuing a regulation, specifying exceptions to the export ban. Para. 3 of the regulation of $1986^{10}$ - adopted on the basis of para. 2(2) of the 1918 Act, provided for example that the public interest does not require that the works of still living artists, or of those deceased for a period of less than 20 years, must remain in the country. However, there were also possible exceptions to this rule, for example when works were considered national treasures. ${ }^{11}$ This act, banning exports of cultural objects of 1918, was repealed by Article II(2) point (1) of the Federal Act of 1999, which amended the Federal Act on restrictions regarding the disposal of objects of historical, artistic or cultural significance ${ }^{12}$.

7 For a historical perspective on the subject, see, e.g., M. Zykan, Zum österreichischen Ausfuhrverbotsgesetz, Geschichte-Problematik-Wirkung, "Österreichische Zeitschrift für Kunst und Denkmalpflege" 1984, Vol. 38, pp. 1-15; F. Hammer, Die geschichtliche Entwicklung des Denkmalrechts in Deutschland, Mohr Siebeck, Tübingen 1995, p. 203.

8 The notion of "public interest" has been equated with the notion of "general interest". This is examined in more detail by E. Frodl-Kraft, op. cit., p. 6.

9 See K.G. Krenz, Rechtliche Probleme des internationalen Kulturgüterschutzes. Durchsetzung, Harmoniesierungsbestrebungen und Restitutionen von Kulturgütern, Peter Lang, Frankfurt am Main 2013, p. 165; J. Sprecher, Beschränkungen des Handels mit Kulturgut und die Eigentumsgarantie, De Gruyter, Berlin 2004, pp. 66 ff.; N. Helfgott, Das Ausfuhrverbotsgesetz für Kulturgut, Manz, Wien 1987; idem, Neue Tendenzen und Normen des Denkmalschutzgesetzes und des Ausfuhrverbotgesetzes für Kulturgut in Österreich, in: G. Reichelt (ed.), Internationaler Kulturgüterschutz. Wiener Symposion 18./19. Oktober, Manz, Wien 1992, pp. $81 \mathrm{ff}$.

10 Verordnung des Bundesministers für Wissenschaft und Forschung vom 5. Juni 1986 betreffend Kulturgut, dessen Aufbewahrung im Inland nicht im öffentlichen Interesse gelegen ist [Regulation of the Federal Minister for Science and Research of 5 June 1986 concerning cultural property whose preservation is not in public interest], BGBI. 1986, No. 324.

11 For more on the Austrian law on protection of national treasures, see W. Wieshaider, Denkmalschutzrecht: Eine systematische Darstellung für die österreichische Praxis, Springer, Wien - New York 2002.

12 Federal Act of 19 August 1999 amending the Bundesgesetz, mit welchem das Bundesgesetz betreffend Beschränkungen in der Verfügung über Gegenstände von geschichtlicher, künstlerischer oder kultureller Bedeutung (Denkmalschutzgesetz - DMSG) geändert wird [Federal Act on restrictions regarding the disposal of objects of historical, artistic or cultural significance], BGBL. 1999, I, Pos. 170. For more on this law, see K.G. Krenz, op. cit., pp. 165 ff.; W. Wieshaider, op. cit.; Ch. Bazil, R. Binder-Krieglstein, N. Kraft, Das österreichische Denkmalschutzrecht: DMSG und Kulturgüterrecht, Durchführungsvorschriften, Unionsrecht, Manz, Wien 2015. Sections paras. 16-23 of this Act governed issues concerning the exports of cultural objects abroad. These provisions facilitated the implementation of Council Directive 93/7/EEC of 15 March 1993 on the return of cultural objects unlawfully removed from the territory of a Member State, OJ L 74, 27.03.1993, p. 74 (hereinafter: Council Directive 93/7/EEC). 
The implementation of Council Directive 93/7/EEC was facilitated by the Federal Act of 15 May 1998. ${ }^{13}$ This act was repealed by section para. 26 sentence 2 of the Federal Act on the return of unlawfully removed cultural objects (Kulturgüterrückgabegesetz - KGRG) of 2016 (i.e. the Act under review here).

\section{Draft Act implementing Directive 2014/60/EU}

\section{Work record}

On 8 June 2015, the Federal Chancellery submitted for public consultation ${ }^{14}$ a draft $\mathrm{t}^{15}$ of the Federal Act on the return of unlawfully removed cultural objects (Kulturrückgabegesetz) (hereinafter: Draft Act). ${ }^{16}$ According to the explanatory statement to this Act, ${ }^{17}$ its aim was to facilitate not only the implementation of Directive 2014/60/EU, but also the implementation into national legislation of the 1970 UNESCO Convention, ratified by Austria in $2015 .{ }^{18}$ The explanatory statement to the Draft Act emphasized that the Convention, not being self-executing in its legal nature, was applicable in all Member States bordering with Austria with the exception of Liechtenstein, and that the isolated position of Austria might lead to the implication that it supports the illicit trade in cultural objects. The purpose of the Draft Act - which was clearly stated - was to replace the existing act imple-

13 Bundesgesetz zur Umsetzung der Richtlinie 93/7/EWG über die Rückgabe von unrechtmäßig aus dem Hoheitsgebiet eines Mitgliedstaates der Europäischen Gemeinschaft verbrachten Kulturgütern, BGBI. I 1998, Pos. 67. For more on the Act see, e.g., V. Wiese, Der Einfluss des EG-Rechts auf das internationale Sachenrecht der Kulturgüter, Mohr Siebeck, Tübingen 2005, p. 75. With respect to the restitution of cultural objects in the Austrian law before the entry into force of the aforementioned Act, see T. Brückler (ed.), Kunstraub, Kunstbergung und Restitution in Österreich 1938 bis heute, Böhlau, Wien 1999. For more on the implementation of Directive 93/7/EEC by means of the Act of 1998, see S. Spaun, Der Herausgabeanspruch bei Diebstahl oder illegalem Export von Kulturgütern, Peter Lang, Frankfurt am Main 2003, pp. 187 ff., and the diploma thesis of D. Frankl, Die Restitution von Kunst- und Kulturgütern im nationalen, europäischen und internationalen Rechtsvergleich, Universität Wien, Wien 2001, http://www.univie.ac.at/elib/index.php?title=Restitution_von_Kunst__und_Kulturguetern_-_Daphne_Frankl_-_2001 [accessed: 23.12.2016].

14 Cf. G. Schefbeck, Dokumentation Österreich, "Journal für Rechtspolitik" 2015, No. 3, pp. $273 \mathrm{ff}$.

15 https://www.parlament.gv.at/PAKT/VHG/XXV/ME/ME_00135/fname_422706.pdf [accessed: 28.12.2016].

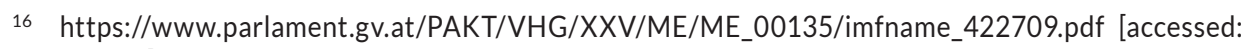
28.12.2016].

17 https://www.parlament.gv.at/PAKT/VHG/XXV/ME/ME_00135/fname_422708.pdf [accessed: 28.12.2016].

18 Übereinkommen über Maßnahmen zum Verbot und zur Verhütung der unzulässigen Einfuhr, Ausfuhr und Übereignung von Kulturgut [Ratification of the Convention on the Prohibition and Prevention of Inadmissible Import, Export and Transfer of Cultural Property], BGBI. III No. 139/2015. The Convention was ratified by the National Council on 21 May 2015, and on 3 June 2015 the Federal Council did not raise any objections; see https://www.ris.bka.gv.at/Dokument.wxe?Abfrage=BgblAuth\&Dokumentnummer=BGBLA_2015_III_139 [accessed: 28.12.2016], and https://www.parlament.gv.at/PAKT/VHG/XXV/I/I_00456/ index.shtml§tab-ParlamentarischesVerfahren [accessed: 28.12.2016]. 
menting Council Directive 93/7/EEC. ${ }^{19}$ The powers of the federal legislator with respect to enactment of an implementing act were derived from Article 10(1) points $13,2,6$ and 8 of the Constitution of Austria. ${ }^{20}$

\section{Aims and objective scope of the Act}

Para. 1 of the Draft Act sets out the objective to be achieved by the new law, which was namely the implementation of Directive 2014/60/EU and of the 1970 UNESCO Convention. In section para. 2 of the proposed draft, two separate definitions of a cultural object were given. The first one refers to Article 2 point 1 of Directive 2014/60/EU and provides that a cultural object is an object which under the law of a European Union (EU) Member State, before or after its unlawful removal from the territory of that Member State, was classified or defined as a national treasure within the meaning of Article 36 of the Treaty on the Functioning of the European Union (TFEU). ${ }^{21}$

At the same time, in accordance with section para. 2 point 2 of the Draft Act, a cultural object is an object that is protected under the provisions of a state party to the 1970 UNESCO Convention as part of the nation's cultural heritage, within the meaning of Articles 1, 4 and 5 of this Convention, and can be recognised as such without any particular difficulties. In the explanatory statement to the Draft Act it was emphasized that, in view of the global applicability of the 1970 UNESCO Convention and the diversified nature of national legislations, it was necessary to refer to the notion which would easily allow to determine whether a specified good is a protected cultural object. In this case, criteria such as the value of the object or the circumstances of its acquisition may be of essential importance. In order to facilitate the identification of the character of an object, para. 7 of the Draft Act provides for the possibility to enter into relevant agreements with parties to the 1970 UNESCO Convention facilitating the recognition of an object as a cultural object.

\section{Notion of "unlawful removal of a cultural object"}

Para. 3 of the Draft Act defines "unlawful removal of a cultural object". In the case of EU Member States, a reference was made to the definition in Article 2 point 2 of Directive 2014/60/EU, adding the date from which the protection against unlawful removable was applicable, the day following 31 December 1992. In the case of the 1970 UNESCO Convention the date adopted as the date from which the protection

19 Some doubts have been raised by the fact that the legislator decided not to amend the existing regulations, and instead chose to enact an entirely new act. Unfortunately, the answer to this question cannot be found in the explanatory statement to the draft act.

20 Text in the German and English languages available at: https://www.vfgh.gv.at/cms/vfgh-site/english/ downloads/englishverfassung.pdf [accessed: 28.12.2016].

21 Treaty on the Functioning of the European Union (consolidated version), OJ C 326, 26.10.2012, p. 47. 
is effective is the day following 31 December 2015.22 "An unlawful removal" covers both removal without the certificate referred to in Article 6 of the 1970 UNESCO Convention and removal as a result of theft within the meaning of section para. 7 of this Convention. In addition, section para. 3(3) of the Draft Act stipulates that the unlawful removal of a cultural object also includes a failure to return a lawfully exported cultural object in a timely fashion (e.g. for the purpose of an exhibition display). ${ }^{23}$

\section{Ban on imports}

Section 4 of the Draft Act provides for a ban on imports to Austria of a cultural good that was unlawfully removed from another EU Member State or a state party to the Convention. There is an exception to the ban in cases where, following the unlawful removal of a cultural good from one of the states belonging to the above-mentioned categories, the state amended the legislation causing the otherwise unlawful remove to be lawful. The explanatory statement to the Draft Act indicated that this might occur in the case of a longer transport of a specified good. The court to which the dispute was submitted - as set forth in section para. 13(1) of the Draft Act - should, according to the explanatory statement to the Draft Act, examine any reversal of the premise of unlawfulness.

\section{List of legal definitions}

Section para. 5 of the Draft Act contains a list of legal definitions, which in part implement the definitions contained in Article 2 of Directive 2014/60/EU. However, the list of definitions was extended to include a definition of a state party to the 1970 UNESCO Convention and the concept of "religious institutions".

Section para. 6(1) point (1) of the Draft Act contains a list of "central authorities", together with a list of their tasks, within the meaning of Article $4 \mathrm{ff}$. of Directive 2014/60/EU. ${ }^{24}$ The Austrian central authorities are the Austrian Federal Monuments Office (Bundesdenkmalamt), and in the case of archive records, the Austrian State Archives (Österreichisches Staatsarchiv). Pursuant to section para. 6(1) sentence 2 of the Draft Act, these authorities are to assist states that request the return of unlawfully removed cultural objects with the identification of such

22 Thus in both cases the act does not apply to removals occurred which before the date of entry into force of the Directive or the Convention - see Article 14 of the Directive.

23 This example is given in the explanatory statement to the draft act.

24 In accordance with the explanatory statement to the draft act, this provision does not apply to the states parties to the UNESCO Convention, which does not contain comparable solutions, while in Article 7 it mentions the necessity to have recourse to "diplomatic channels". Should a successful resolution of a dispute be impossible, legal action shall be appropriate, section para. 10 of the Act. The relevant mechanisms in the enforcement of claims may also be set forth in international agreements, as referred to in the explanatory statement to the draft act. 
objects. ${ }^{25}$ Section para. 6(2) of the Draft Act sets out a long list of the central authorities further duties - referring to the list provided in Article 5 of Directive 2014/60/EU. At the same time, section para. 8 of the Draft Act elaborates special solutions in the event of exceptional circumstances, such as natural disasters or armed conflicts, in the course of which a state party to the Convention is unable to prevent the removal of cultural objects. In this case the federal government of Austria may, by regulation, allow for the identification of an imported cultural object. ${ }^{26}$

\section{Obligations of care and attention}

Section para. 9 of the Draft Act defined the obligations imposed on persons professionally engaged in the trade in cultural objects ${ }^{27}$. The authors of the Draft Act assumed that these persons must meet the standards of a diligent entrepreneur. The provisions of the Draft Act define the obligations of care and attention in a detailed manner. Above all, all persons professionally engaged in trade in cultural objects are obliged to endeavour not to transfer (whether against payment or free of charge) cultural property that was unlawfully imported into Austria. Furthermore, before the transfer of cultural property they are obligated to advise the buyer, without request and in a documented manner, of the origin of the cultural object. The following obligation is keeping records that identify a cultural object, its origin, the purchase and sale price, and export licenses. According to the Draft Act, the records must be kept for seven years from the transfer of an object of cultural property. To justify this provision in the Draft Act, it was stated that the market for cultural objects requires a buyer to have reliable information on the origin of the object, thus reducing the risk of claims for the return of a cultural object brought by former owners. Any intentional violation of the obligations set out in Section para. 9 of the Act are subject to a fine, as set forth in Section para. 23 of the Act.

\section{Pursuing claims}

The second chapter of the Draft Act, paras. 10-17, concerns the pursuit of claims for the return of cultural objects in Austria. The implementation of section para. 8 of Directive 2014/60/EU is facilitated by paras. 10(1) and 12 of the Draft Act. Following the Directive, the national legislator provided for the possibility of initiating

\footnotetext{
25 In the explanatory statement to the draft act, it has been indicated that alongside their coordinating role, the central authorities will also participate in the International Market Information System (IMI).

26 The explanatory statement to the draft act referred to Regulation (EC) No. 1210/2003 of 7 July 2003 concerning certain specific restrictions on economic and financial relations with Iraq and repealing Regulation (EC) No. 2465/96, OJ L 169, 8.07.2003, p. 6. See Article 3(2) (b) of this regulation.

27 In the explanatory statement to the draft act, it has been emphasised that the proposed solutions are comparable to those set out in Article 16 of the Kulturgütertransfergesetz [Swiss Federal Act on the International Transfer of Cultural Objects of 20 June 2003], AS 2005, pp. 1869 ff., as amended.
} 


\section{RESEARCH ARTICLES}

Bernard Łukańko

return proceedings within three years from the time when information on the location of the cultural object, and on the identity of the holder or possessor comes to the knowledge of the requesting Member State. In principle (with exceptions provided for in the Act), the claim is cancelled after a period of thirty years from the unlawful removal of a cultural object from the territory of the requesting Member State, regardless of information available to the requesting Member State.

\section{Court jurisdiction}

Para. 11 of the Draft Act regulates the subject matter and territorial jurisdiction of the court ruling on a claim to return a cultural object. The subject matter jurisdiction shall be vested in the district court (Landgericht), while the court of the district where the defendant resides, or has her/his official office, shall exercise territorial jurisdiction. In para. 11(3) of the Draft Act the Austrian lawmaker conferred on the Treasury the status of a party to the proceedings for the return of cultural objects. In accordance with para. 13 of the Draft Act, the proceedings are subject to the principle of limited validity, i.e. the court verifies not only if the premises of para. 4 of the act have been met (unlawful removal), but also whether at the time when the case was brought before the court (referred to as a motion (Antrag) according to the definitions contained in the act) the claim had not expired. It seems that this solution complies with Articles 8(2) and 9 of Directive 2014/60/EU. Para. 13(2) of the Draft Act provides that the burden of proof shall lie with the Member State initiating the claim. Para. 14 of the Draft Act defines regulates the governing law to be applied to assess the ownership status after the return of the cultural good, ${ }^{28}$ the law of the requesting Member State is applied. This provision constitutes the implementation of Article 13 of the Directive 2014/60/EU.

\section{Compensation and other claims}

Para. 15 of the Draft Act facilitates the implementation of Article 10 of the Directive 2014/60/EU. It regulates the question of compensation due to the possessor of the cultural object that was unlawfully removed. This provision states that:

The court shall obligate the requesting Member State to award the possessor fair compensation, provided that the possessor demonstrates that he exercised due care and attention in acquiring the cultural object.

28 For more on the governing law applicable to determine the property status with respect to cultural objects - S. Arnold, Eigentumsschutz und Verkehrsschutz bei Kunstgegenständen im östereichischen Kollisions- und Privatrecht, "Austrian Law Journal" 2015, No. 1, pp. 3 ff. 
In determining whether the possessor exercised "due care and attention", as provided for in Article 10 para. 2 of the Directive 2014/60/EU:

consideration shall be given to all the circumstances of the acquisition, in particular the documentation on the object's provenance, the authorisations for removal required under the law of the requesting Member State, the character of the parties, the price paid, whether the possessor consulted any accessible register of stolen cultural objects and any relevant information which he could reasonably have obtained, or took any other step which a reasonable person would have taken in the circumstances.

Para. 15(4) of the Draft Act provides that a lien, or another limited right in rem, on the cultural object subject to return shall also include a claim for compensation. Para. 16(1) of the Draft Act provides that a buyer acting with due care and attention shall have the right to claim reimbursement of the costs of proceedings, including the costs of legal representation, from the requesting Member State. In addition, pursuant to para. 16(2) of the Draft Act, the court may impose on a Member State the obligation to reimburse the costs of return and of maintaining the object. In accordance with para. 17(1) of the Draft Act, an owners' claim to return a stolen object shall have precedence over the claim of the state requesting its return.

\section{Austria's claim to return a cultural object}

The third chapter of the Draft Act regulates the claims of the Republic of Austria for the return of cultural objects. Pursuant to para. 18(1) sentence 1 of the Draft Act, the enforcement of claims for return shall be executed by the competent central authority, for both extra-judicial and judicial proceedings. the approval of the Federal Chancellor must be obtained Before bringing a claim before the court, except in cases of urgency. In accordance with para. 19 of the Draft Act, the Treasury may raise a recourse claim against person/s responsible for the unlawful removal of a cultural object.

\section{Criminal liability}

The fourth and last chapter contains final provisions, criminal liability provisions (para. 23), ${ }^{29}$ and provisions governing the entry into force of the act (para. 26). An interesting provision in this respect is para. 21 of the Draft Act which sets out

\footnotetext{
29 Section para. 23 of the Act, which provides for criminal law provisions, specifies a wide range of acts which are subject to a fine. Here it is worth mentioning the most significant ones. The intentional import into Austria of a cultural good contrary to the provisions of Section para. 4 is subject to a fine of 50,000 EUROs. A similar penalty may also be imposed for an intentional transfer (against payment or free of charge) of the title to such a cultural object contrary to the provisions of Section para. 9 point 1 of the Act. Attempts to commit these acts are also punishable. A fine of up to 25,000 EUROs can be imposed for an intentional failure to draw up records specified in Section para. 9 point 2 of the Act or for intentionally destroying such records before the lapse of 30 years.
} 
the duty of every person to provide information, and make the disputed cultural object available for examination by administrative and judicial authorities. This is a broader solution, in both subjective and objective terms, than the one contained in Article 20 para. 4 of the Constitution of Austria. ${ }^{30}$

\section{Consultation procedure}

In June and July 2015, the Draft Act submitted by the Chancellery Office ${ }^{31}$ - together with a document containing the impact assessment of this legislation ${ }^{32}$ - were presented for a comprehensive consultation. Ten entities expressed their opinions: the bar council:;3 offices of provincial governments: ${ }^{34}$ Salzburg ${ }^{35}$, Vorarlberg ${ }^{36}, \mathrm{Ti}$ rol $^{37}$ and Upper Austria ${ }^{38}$; the Austrian Economic Chamber; ${ }^{39}$ and the Federal min-

30 The provision reads as follows: "All the authorities entrusted with the federal, provincial or municipal administration as well as authorities of other public law entities should supply information within their scope of activities, provided that it is not contrary to the statutory obligation of official confidentiality; union delegations are obliged to supply information only to persons belonging thereto and in so far as it does not prevent proper exercise of their statutory functions. More detailed rules relating to the authorities of the federation as well as to self-government governed by federal legislation lie within the scope of powers of the federation, while those relating to provincial and municipal authorities as well as self-government governed by national legislation, lie within the scope of powers of the federation as far as legislation on principles is concerned, and as far as executive legislation and execution is concerned, they lie within the scope of powers of the provinces." Quoted after the Federal Constitutional Law of the Republic of Austria of 1 October 1920 (according to the consolidated text of the Federal Constitutional Law of 1 January 1930 [version of 7 December 1929]) https://www.ris.bka.gv.at/Dokument.wxe?Abfrage=Erv\&Dokumentnummer=ERV_1930_1 [accessed: 28.12.2016].

31 https://www.parlament.gv.at/PAKT/VHG/XXV/ME/ME_00135/imfname_422709.pdf [accessed: 28.12.2016].

32 https://www.parlament.gv.at/PAKT/VHG/XXV/ME/ME_00135/fname_422707.pdf [accessed: 28.12.2016].

33 https://www.parlament.gv.at/PAKT/VHG/XXV/SNME/SNME_04213/imfname_432017.pdf [accessed: 28.12.2016].

34 These entities did not express objections to the draft act and did not propose significant amendments.

35 https://www.parlament.gv.at/PAKT/VHG/XXV/SNME/SNME_04244/imfname_437994.pdf [accessed: 28.12.2016].

36 https://www.parlament.gv.at/PAKT/VHG/XXV/SNME/SNME_04229/imfname_436411.pdf [accessed: 28.12.2016].

37 https://www.parlament.gv.at/PAKT/VHG/XXV/SNME/SNME_04249/imfname_439315.pdf [accessed: 28.12 .2016$]$.

38 https://www.parlament.gv.at/PAKT/VHG/XXV/SNME/SNME_04272/imfname_444557.pdf [accessed: 28.12 .2016$]$.

39 https://www.parlament.gv.at/PAKT/VHG/XXV/SNME/SNME_04255/imfname_440343.pdf [accessed: 28.12.2016]. The Chamber pointed out, inter alia, the issue of the absence of a relevant register of cultural objects in Austria. 
istries of the Interior ${ }^{40}$, of Justice ${ }^{41}$, of Finance ${ }^{42}$ and for Europe, Integration and Foreign Affairs. ${ }^{43}$ The scope of comments submitted varied and ranged from full acceptance of the Draft Act to raising - by the bar leaders - fundamental questions as to the risk of the possible, but prohibited, retroactive application of penal provisions.

\section{Parliamentary work}

The Draft Act was submitted to the lower house of the Austrian Parliament (Nationalrat) on 10 November 2015. At the $101^{\text {st }}$ session of the National Council, the Draft Act was sent to the Commission for Culture (Kulturauschuss). The Draft Act was then discussed at the 10th session of the Commission on 2 March 2016. In the course of these discussions an amendment to para. 9 of the Draft Act was proposed, adding more detail to the provisions and extending from 7 to 30 years the period for which records relating to a cultural object must be kept; the records should also contain information about the person importing the cultural object, and on all authorisations for border crossing (when the object crosses many borders). ${ }^{44}$ On the $119^{\text {th }}$ session of the National Council on 17 March 2016, deputies moved to the $2^{\text {nd }}$ and $3^{\text {rd }}$ readings of the Draft Act, and then they adopted it, as amended..$^{45}$ On 21 March 2016, the Draft Act, together with amendments, was submitted to the upper house of Parliament - The Federal Council (Bundesrat) and was addressed to the Commission of Education, Art and Culture (Ausschuss für Unterricht, Kunst und Kultur). In its report of 29 March 2016, ${ }^{46}$ the Commission decided not to raise

\footnotetext{
40 https://www.parlament.gv.at/PAKT/VHG/XXV/SNME/SNME_04250/imfname_439317.pdf [accessed: 28.12.2016]. The Ministry of Interior proposed significant amendments in section para. 9 of the draft act relating to the obligation of taking photographs of the object concerned as well as to the extension to 30 years of the period for information storage.

41 https://www.parlament.gv.at/PAKT/VHG/XXV/SNME/SNME_04271/imfname_443396.pdf [accessed: 28.12.2016]. The Ministry of Justice pointed out, inter alia, the issue of additional burdens, both personal and financial, on the court handling cases for the return of cultural objects.

42 https://www.parlament.gv.at/PAKT/VHG/XXV/SNME/SNME_04268/imfname_442070.pdf [accessed: 28.12.2016]. In the view of the Ministry of Finance, the draft act and the "Impact Assessment of the Legislative Act" attached thereto do not take into consideration the financial burden resulting from the entry into force of the law.

43 https://www.parlament.gv.at/PAKT/VHG/XXV/SNME/SNME_04288/imfname_446079.pdf [accessed: 28.12.2016]. This opinion focuses on issues of terminology adjustments in the explanatory statement to the draft act.

44 https://www.parlament.gv.at/PAKT/VHG/XXV/I/I_01015/fname_513805.pdf [accessed: 30.12.2016].

45 https://www.parlament.gv.at/PAKT/VHG/XXV/BNR/BNR_00302/fname_518917.pdf [accessed: 30.12.2016].

46 https://www.parlament.gv.at/PAKT/VHG/BR/I-BR/I-BR_09550/fname_521002.pdf [accessed: 30.12.2016].
} 
objections to it. ${ }^{47}$ The Draft Act as amended was examined by Parliament at the 852nd session of the Federal Council on 31 March 2016. The Federal Council did not raise any objections to it. ${ }^{48}$ As mentioned above, the Act was published in the Official Journal (Bundesgesetzblatt) of 13 April 2016 under item 19.

\section{Assessment of the act and conclusions}

First of all it should be noted that, despite a certain delay, Austria implemented Directive 2014/60/EU rather quickly. Taking into account the ratification of the 1970 UNESCO Convention in 2015, which was also transposed into national legislation by the Act discussed in this paper, one can observe that Austria's interest in combating illegal imports of cultural objects has grown considerably. This change is even more significant taking into account that the implementation of the previous Council Directive 93/7/EEC, was delayed in Austria by a few years and triggered EU proceedings, initiated by the European Commission, ${ }^{49}$ for treaty infringement. ${ }^{50}$ A review of the practical application of national legislation based on Council Directive 93/7/EEC showed that the vast majority of claims for the return of unlawfully removed cultural objects were pursued in extra-judicial proceedings, and only a few cases ended with court proceedings. ${ }^{51}$ At the same time, from the year 2005 nine out of the 14 proceedings, conducted in accordance with the national legislation facilitating the implementation of Article 5 of Council Directive 93/7/EEC throughout the EU, were motions filed against Austria..$^{52}$ Therefore, it was in the interest of Austria (regardless of the principle of loyalty in $\mathrm{EU} \mathrm{law}^{53}$ ) to carry out a full

47 Article 42 of the Constitution of Austria (consolidated version), https://www.ris.bka.gv.at/Dokumente/ Erv/ERV_1930_1/ERV_1930_1.pdf [accessed: 30.12.2016].

48 https://www.parlament.gv.at/PAKT/VHG/XXV/BNR/BNR_00302/fname_521758.pdf [accessed: 30.12.2016].

49 Report from the Commission to the Council, the European Parliament and the Economic and Social Committee of 25 May 2000 on the implementation of Council Regulation (EEC) No. 3911/92 on the export of cultural goods and Council Directive 93/7/EEC on the return of cultural objects unlawfully removed from the territory of a Member State, $\operatorname{COM(2000)} 325$ final, p. 13.

50 Currently Article 258 TFEU.

51 Cf. four Reports from the Commission to the Council, the European Parliament and the European Economic and Social Committee on the application of Council Directive 93/7/EEC: 1) Report from the Commission to the Council, the European Parliament and the Economic and Social Committee of 25 May 2000, op. cit., pp. 23ff.; 2) Second report on the application of Council Directive 93/7/EEC on the return of cultural objects unlawfully removed from the territory of a Member State, 21 December 2005, COM(2005) 675 final, pp. 16 ff.; 3) Third report on the application of Council Directive 93/7/EEC on the return of cultural objects unlawfully removed from the territory of a Member State, 30 July 2009, COM(2009) 408 final, pp. $10 \mathrm{ff}$;; 4) Fourth report on the application of Council Directive 93/7/EEC on the return of cultural objects unlawfully removed from the territory of a Member State, 30 May 2013, COM(2013) $310 \mathrm{final}$, pp. $10 \mathrm{ff}$.

52 Third report on the application of Council Directive 93/7/EEC, op. cit., pp. $11 \mathrm{ff}$.; Fourth report on the application of Council Directive 93/7/EEC, op. cit., pp. $13 \mathrm{ff}$.

53 Currently Article 4(3) of the Treaty on European Union (consolidated version), OJ C 326, 26.10.2012, p. 13. 
implementation of the new Directive 2014/60/EU. The Act of 2016, concerning the implementation of not only Directive 2014/60/EU but also of the 1970 UNESCO Convention, was an expression of respect for other cultures, and for their cultural objects. The solution that was ultimately adopted by the Austrian Parliament with respect to the obligations of professionals engaged in the trade of cultural objects, including the requirement that information be retained by an organisation for 30 years, makes the Austrian Act similar to the solutions of other countries (including outside the EU). ${ }^{54}$

In spite of the generally high assessment of the 2016 Act, its defects should not be overlooked. First, the narrow subjective scope of persons liable for care and attention in the trade in cultural objects has been criticised. For example, para. 9 of the Austrian Act applies only to persons professionally engaged in the trade of cultural objects, while para. $41 \mathrm{ff}$. of the German Act implementing Directive 2014/60/EU provides that the duty of care and attention applies to any person who places a cultural object on the market. ${ }^{55}$ One may also criticise the absence in the Austrian Act of any provisions requiring care and attention in transactions relating to objects removed from 30 January 1933 to 8 May 1945 by fascist Germany (cf. para. 44 sentence 1 point 1 of the aforementioned German act).

Despite these important defects, it seems that the Act could significantly reduce the illicit trafficking of cultural objects from other states into the territory of Austria. The new solutions, including longer periods for pursuing claims, will allow authorized persons to recover lost cultural objects in more cases. A practical assessment of the application of the Act will only be possible in a few years; including in the framework of the reports referred to in Article 17 of Directive 2014/60/EU. ${ }^{56}$

\section{References}

Arnold S., Eigentumsschutz und Verkehrsschutz bei Kunstgegenständen im östereichischen Kollisions- und Privatrecht, "Austrian Law Journal" 2015, No. 1.

Ausfuhrverbotsgesetz für Kulturgut (AusfVKG) [Austrian Act of 5 December 1918 on the protection of cultural objects and the ban on exports of cultural objects], StGBI. No. 90/1918, as amended.

Bazil Ch., Binder-Krieglstein R., Kraft N., Das österreichische Denkmalschutzrecht: DMSG und Kulturgüterrecht, Durchführungsvorschriften, Unionsrecht, Manz, Wien 2015.

\footnotetext{
54 See, e.g., Article 16(3) of the Swiss Federal Act on the International Transfer of Cultural Objects, op. cit.

55 Gesetz zur Neuregelung des Kulturgutschutzrechts - KGSG [Act of 31 July 2016 Reforming the Law on the Protection of Cultural Property], Bundesgesetzblatt (BGBI.) 2016 I S. 1914, entered into force on 6 August 2016, http://www.gesetze-im-internet.de/kgsg/index.html [accessed: 21.09.2016].

56 As part of the "impact assessment of the draft act" an internal evaluation of the Act is planned for 2020. The adoption of this quite remote date results from the projected limited number of cases whereby the Act is supposed to be applied in the near future. See https://www.parlament.gv.at/PAKT/VHG/XXV/ME/ ME_00135/fname_422707.pdf [accessed: 30.12.2016].
} 
Brückler T. (ed.), Kunstraub, Kunstbergung und Restitution in Österreich 1938 bis heute, Böhlau, Wien 1999.

Constitution of Austria (consolidated version), https://www.ris.bka.gv.at/Dokumente/Erv/ ERV_1930_1/ERV_1930_1.pdf [accessed: 30.12.2016].

Council Directive 93/7/EEC of 15 March 1993 on the return of cultural objects unlawfully removed from the territory of a Member State, OJ L 74, 27.03.1993, p. 74.

Directive 2014/60/EU of the European Parliament and of the Council of 15 May 2014 on the return of cultural objects unlawfully removed from the territory of a Member State and amending Regulation (EU) No 1024/2012, OJ L 159, 28.05.2014, p. 1.

Bundesgesetz zur Umsetzung der Richtlinie 93/7/EWG über die Rückgabe von unrechtmäßig aus dem Hoheitsgebiet eines Mitgliedstaates der Europäischen Gemeinschaft verbrachten Kulturgütern [Federal Act of 15 May 1998 implementing Directive 93/7/EEC of 15 March 1993 on the return of cultural objects unlawfully removed from the territory of a Member State], BGBI. I 1998, Pos. 67.

Bundesgesetz, mit welchem das Bundesgesetz betreffend Beschränkungen in der Verfügung über Gegenstände von geschichtlicher, künstlerischer oder kultureller Bedeutung (Denkmalschutzgesetz - DMSG) geändert wird [Federal Act of 19 August 1999 amending the Federal Act on restrictions regarding the disposal of objects of historical, artistic or cultural significance], BGBL. 1999, I, Pos. 170.

Bundesgesetz über die Rückgabe unrechtmäßig verbrachter Kulturgüter (Kulturgüterrückgabegesetz - KGRG) [Federal Act on the return of unlawfully removed cultural objects], 13 April 2016, Bundesgesetzblatt für die Republik Österreich, 2016, T. I, Pos. 19.

Federal Constitutional Law of the Republic of Austria of 1 October 1920 (according to the consolidated text of the Federal Constitutional Law of 1 January 1930 [version of 7 December 1929]), https://www.ris.bka.gv.at/Dokument.wxe?Abfrage=Erv\&Dokumentnummer=ERV_1930_1 [accessed: 28.12.2016].

Fourth Report from the Commission to the European Parliament, the Council and the European Economic and Social Committee on the application of Council Directive 93/7/ EEC on the return of cultural objects unlawfully removed from the territory of a Member State, Bruxelles, 30 May 2013, COM (2013) final.

FrankI D., Die Restitution von Kunst- und Kulturgütern im nationalen, europäischen und internationalen Rechtsvergleich, Universität Wien, Wien 2001, http://www.univie.ac.at/elib/index.php?title=Restitution_von_Kunst-_und_Kulturguetern_-_Daphne_Frankl_-_2001 [accessed: 23.12.2016].

Frodl-Kraft E., Gefährdetes Erbe: Österreichs Denkmalschutz und Denkmalpflege 1918-1945 im Prisma der Zeitgeschichte, Böhlau Verlag, Wien 1997.

Gesetz zur Neuregelung des Kulturgutschutzrechts - KGSG [Act of 31 July 2016 Reforming the Law on the Protection of Cultural Property], Bundesgesetzblatt (BGBI.) 2016 I S. 1914, entered into force on 6 August 2016, http://www.gesetze-im-internet.de/kgsg/ index.html [accessed: 21.09.2016].

Hammer F., Die geschichtliche Entwicklung des Denkmalrechts in Deutschland, Mohr Siebeck, Tübingen 1995.

Helfgott N., Das Ausfuhrverbotsgesetz für Kulturgut, Manz, Wien 1987.

Helfgott N., Neue Tendenzen und Normen des Denkmalschutzgesetzes und des Ausfuhrverbotgesetzes für Kulturgut in Österreich, in: G. Reichelt (ed.), Internationaler Kulturgüterschutz. Wiener Symposion 18./19. Oktober, Manz, Wien 1992. 
https://www.parlament.gv.at/PAKT/VHG/BR/I-BR/I-BR_09550/fname_521002.pdf [accessed: 30.12.2016].

https://www.parlament.gv.at/PAKT/VHG/XXV/BNR/BNR_00302/fname_518917.pdf [accessed: 30.12.2016].

https://www.parlament.gv.at/PAKT/VHG/XXV/BNR/BNR_00302/fname_521758.pdf [accessed: 30.12.2016].

https://www.parlament.gv.at/PAKT/VHG/XXV/I/I_00456/index.shtml§tab-ParlamentarischesVerfahren [accessed: 28.12.2016].

https://www.parlament.gv.at/PAKT/VHG/XXV/I/I_01015/fname_513805.pdf [accessed: 30.12.2016].

https://www.parlament.gv.at/PAKT/VHG/XXV/ME/ME_00135/fname_422706.pdf [accessed: 28.12.2016].

https://www.parlament.gv.at/PAKT/VHG/XXV/ME/ME_00135/fname_422707.pdf [accessed: 28.12.2016].

https://www.parlament.gv.at/PAKT/VHG/XXV/ME/ME_00135/fname_422708.pdf [accessed: 28.12.2016].

https://www.parlament.gv.at/PAKT/VHG/XXV/ME/ME_00135/imfname_422709.pdf [accessed: 28.12.2016].

https://www.parlament.gv.at/PAKT/VHG/XXV/SNME/SNME_04213/imfname_432017. pdf [accessed: 28.12.2016].

https://www.parlament.gv.at/PAKT/VHG/XXV/SNME/SNME_04229/imfname_436411. pdf [accessed: 28.12.2016].

https://www.parlament.gv.at/PAKT/VHG/XXV/SNME/SNME_04244/imfname_437994. pdf [accessed: 28.12.2016].

https://www.parlament.gv.at/PAKT/VHG/XXV/SNME/SNME_04249/imfname_439315. pdf [accessed: 28.12.2016].

https://www.parlament.gv.at/PAKT/VHG/XXV/SNME/SNME_04250/imfname_439317. pdf [accessed: 28.12.2016].

https://www.parlament.gv.at/PAKT/VHG/XXV/SNME/SNME_04255/imfname_440343. pdf [accessed: 28.12.2016].

https://www.parlament.gv.at/PAKT/VHG/XXV/SNME/SNME_04268/imfname_442070. pdf [accessed: 28.12.2016].

https://www.parlament.gv.at/PAKT/VHG/XXV/SNME/SNME_04271/imfname_443396. pdf [accessed: 28.12.2016].

https://www.parlament.gv.at/PAKT/VHG/XXV/SNME/SNME_04272/imfname_444557. pdf [accessed: 28.12.2016].

https://www.parlament.gv.at/PAKT/VHG/XXV/SNME/SNME_04288/imfname_446079. pdf [accessed: 28.12.2016].

https://www.ris.bka.gv.at/Dokument.wxe?Abfrage=Bgb|Auth\&Dokumentnummer=BGBLA_2015_III_139 [accessed: 28.12.2016].

https://www.vfgh.gv.at/cms/vfgh-site/english/downloads/englishverfassung.pdf [accessed: 28.12.2016].

Krenz K.G., Rechtliche Probleme des internationalen Kulturgüterschutzes. Durchsetzung, Harmoniesierungsbestrebungen und Restitutionen von Kulturgütern, Peter Lang, Frankfurt am Main 2013. 
Kulturgütertransfergesetz [Swiss Federal Act on the International Transfer of Cultural Objects of 20 June 2003], AS 2005, pp. 1869 ff., as amended.

Regulation (EC) No. 1210/2003 of 7 July 2003 concerning certain specific restrictions on economic and financial relations with Iraq and repealing Regulation (EC) No. 2465/96, OJ L 169, 8.07.2003, p. 6.

Report from the Commission to the Council, the European Parliament and the Economic and Social Committee of 25 May 2000 on the implementation of Council Regulation (EEC) No. 3911/92 on the export of cultural goods and Council Directive 93/7/EEC on the return of cultural objects unlawfully removed from the territory of a Member State, $\operatorname{COM}(2000) 325$ final, p. 13.

Schefbeck G., Dokumentation Österreich, "Journal für Rechtspolitik" 2015, No. 3.

Second Report from the Commission to the European Parliament, the Council and the European Economic and Social Committee on the application of Council Directive 93/7 on the return of cultural objects unlawfully removed from the territory of a Member State, Bruxelles, 21 December 2005, COM (2005) 675 final.

Spaun S., Der Herausgabeanspruch bei Diebstahl oder illegalem Export von Kulturgütern, Peter Lang, Frankfurt am Main 2003.

Sprecher J., Beschränkungen des Handels mit Kulturgut und die Eigentumsgarantie, De Gruyter, Berlin 2004.

Third Report from the Commission to the European Parliament, the Council and the European Economic and Social Committee on the application of Council Directive 93/7 on the return of cultural objects unlawfully removed from the territory of a Member State, Bruxelles, 30 July 2009, COM (2009) 408 final.

Treaty on European Union (consolidated version), OJ C 326, 26.10.2012, p. 13.

Treaty on the Functioning of the European Union (consolidated version), OJ C 326 , 26.10.2012, p. 47.

UNESCO Convention on the Means of Prohibiting and Preventing the Illicit Import, Export and Transfer of Ownership of Cultural Property, 14 November 1970, 823 UNTS 231.

Ustawa o narodowych dobrach kultury - projekt [Polish Draft Act on National Cultural Objects], http://bip.kprm.gov.pl/kpr/form/r2047,Projekt-ustawy-o-narodowych-dobrach-kultury.html [accessed: 29.12.2016].

Übereinkommen über Maßnahmen zum Verbot und zur Verhütung der unzulässigen Einfuhr, Ausfuhr und Übereignung von Kulturgut [Ratification of the Convention on the Prohibition and Prevention of Inadmissible Import, Export and Transfer of Cultural Property], BGBI. III No. 139/2015.

Verordnung des Bundesministers für Wissenschaft und Forschung vom 5. Juni 1986 betreffend Kulturgut, dessen Aufbewahrung im Inland nicht im öffentlichen Interesse gelegen ist [Regulation of the Federal Minister for Science and Research of 5 June 1986 concerning cultural property whose preservation is not in public interest], BGBI. 1986, No. 324.

Wiese V., Der Einfluss des EG-Rechts auf das internationale Sachenrecht der Kulturgüter, Mohr Siebeck, Tübingen 2005.

Wieshaider W., Denkmalschutzrecht: Eine systematische Darstellung für die österreichische Praxis, Springer, Wien - New York 2002.

Zykan M., Zum österreichischen Ausfuhrverbotsgesetz, Geschichte-Problematik-Wirkung, "Österreichische Zeitschrift für Kunst und Denkmalpflege" 1984, Vol. 38. 